\title{
Asian University Presses in the Digital Age
}

\section{Paul H. Kratoska}

Paul H. Kratoska is managing director, NUS Press, National University of Singapore, Singapore. E-mail: kratoska@nus.edu.sg.

University presses in Asia and the West publish scholarly material, with limited commercial appeal, and face common problems arising from falling sales, rising costs, and the shift to electronic media for teaching materials. However, in North America a large number of presses are competing for a shrinking market, while Asia represents a growing market, especially for English-language publishing. Electronic publications have begun to appear in the region, but their effects are difficult to predict.

In 1950, there were more than 60 university presses in North America but just 12 in East Asia, where most scholarly publishing was handled by commercial academic presses. The final decades of the century brought a dramatic upsurge in university publishing in the latter region: China now has more than 110 university presses, Korea more than 70, Japan more than 30, and in Southeast Asia nearly every major university operates a press.

This development came at a time when North American university presses were running into serious difficulties. Sales had dropped to 500 copies or less per title, and much talk was focused on a crisis in academic publishing. Commercial academic presses responded to the situation by raising prices to $\$ 150$ or more per copy and selling almost exclusively to libraries; but university presses, operating as not-for-profit educational publishers, attempted to maintain more affordable prices. To earn 
additional income, some offered trade publications—coffee-table books, cookbooks, hiking guides, bird-watching manuals, and the like. University publishers also began asking authors to provide subventions to support their books.

\section{Asian Trends}

University presses in East Asia operate on a different basis. In China, they are expected to cover a significant portion of their expenses and make a financial contribution to the university. Much of their output forms textbooks and general readings; and authors of scholarly research works are expected to cover publication costs, generally with funds obtained from university grants. In Japan, university press publications are heavily subsidized by foundations, university research grants, or government bodies such as the Japan Society for the Promotion of Science. In Southeast Asia, university presses tend to follow the American model, relying on a combination of sales and university grants to survive.

The focus of university publishing in East Asia has been changing. While textbooks remain important, research publications now make up 80 percent of the output in Japan, and around half in Korea and China. Most of this material is written in Asian languages, which limits sales to the domestic market; but the best titles represent exceptional scholarship and deserve much wider dissemination.

The top Asian universities now aspire to meet international standards for research. Their goals are to strengthen the university's reputation in order to attract research grants and government funding and to have faculty members develop international visibility. University rankings, such as those produced by the Times Higher 
Education and the (Shanghai) Academic Ranking of World Universities, offer a route to international recognition and have been embraced by university administrations. Because faculty publications play a significant role in determining the ranking of an institution, these listings have produced an increased emphasis on research.

The indexes produced by the Thomson Reuters Institute for Scientific Information (ISI) are one standard measure of research quality, and some Asian universities place a premium on publication in any of the roughly 12,000 journals monitored for the ISI indexes. (For example, the University of Malaya expects members of the academic staff to publish 16 articles in ISI journals to qualify for promotion to full professor.) Nearly all ISI journals are in English, and partly for that reason universities place a premium on English-language publishing. For promotion and tenure exercises in China and Korea, publications in English are worth more than publications in Chinese or Korean. Japanese universities give equal weight to articles or books in English and Japanese, but junior scholars are under considerable pressure to publish some of their research findings in English.

For many disciplines, the emphasis on citations has led to a shift from books to articles as the primary locus of academic discussion in the West, a trend that is less apparent in Asia. Scholars in East Asia continue to build personal libraries and in the arts and social sciences to value books over journal articles.

Asian scholars are encouraged to submit English-language manuscripts to publishers that are deemed prestigious. Determining which presses or academic journals qualify as prestigious is fraught with difficulty, for administrators make this determination not only for a wide range of academic disciplines but also for publishers 
operating half a world away. Commercial academic presses with an international presence, most of them based in Western Europe, offer familiar brand names and have benefited from the administrators' dilemma.

\section{Asian Futures}

Two Asian university presses, NUS Press (formerly Singapore University Press) and Hong Kong University Press, publish primarily in English. Both have altered their publishing profiles over the past decade, moving away from an emphasis on local topics and developing strong lists of titles on East and Southeast Asia for international distribution. They struggle to overcome local perceptions that publication in the West is preferable to publication at home, but scholars in China, Japan, and Korea are often as interested in reaching the wider Asian market as they are in selling books in the West and see publishing in Hong Kong or Singapore as a way to accomplish that objective.

The growth of electronic publishing complicates the situation. Scholars in East Asia continue to value printed books and to build personal libraries. However, the major Asian universities, like those in North America, now offer course readings in electronic formats that can be accessed on personal computers, and students rarely if ever go to the library or handle physical books in preparing course assignments. With appropriate pricing, electronic materials have the potential to improve educational standards generally across Asia, where many universities have long struggled to operate with inadequate library facilities.

E-book readers of the sort that have been available for several years in North America are just beginning to appear in Asia, but the extent to which they will be used 
by scholars to read academic materials is not yet clear. The same is true of such readers' impact on academic publishing. University presses in Asia, as elsewhere, need to find ways to produce and sell electronic editions of the material they publish, and most lack the resources to develop their own e-press. A solution may lie in issuing e-books through publishing consortia, but it is also possible that e-books will complete the ascendancy of large commercial publishing operations. 